Media Kesmas (Public Health Media)
e-ISSN 2776-1339
https://jom.htp.ac.id/index.php/kesmas

\title{
PROGRAM PERBAIKAN GIZI KURANG PADA BALITA \\ DI WILAYAH KERJA PUSKESMAS SIDOMULYO \\ KOTA PEKANBARU
}

\section{PROGRAM FOR IMPROVING LESS NUTRITION FOR CHILDREN IN THE WORKING AREA OF PUSKESMAS SIDOMULYO PEKANBARU}

\author{
Rhomadhon Maghfiroh', Reno Renaldi ${ }^{2}$, Yeyen Gumayesty ${ }^{3}$ \\ 1,2,3 STIKes Hang Tuah Pekanbaru
}

\begin{tabular}{|c|c|}
\hline Histori artikel & Abstrak \\
\hline \multirow{2}{*}{$\begin{array}{l}\text { Received: } \\
\text { 24-11-2020 }\end{array}$} & ABSTRAK \\
\hline & $\begin{array}{l}\text { Gizi kurang menjadi salah satu masalah gizi utama di Indonesia sehingga } \\
\text { Pemerintah menekankan program perbaikan gizi dengan sasaran } \\
\text { meningkatkan derajat kesehatan dan status gizi masyarakat. Puskesmas }\end{array}$ \\
\hline \multirow{2}{*}{$\begin{array}{l}\text { Accepted: } \\
03-12-2021\end{array}$} & Sidomulyo merupakan wilayah dengan angka kejadian gizi kurang pada \\
\hline & umum mengenai program perbaikan gizi kurang dengan metode \\
\hline \multirow{5}{*}{$\begin{array}{l}\text { Published: } \\
\text { 12-12-2021 }\end{array}$} & di Puskesmas Sidomulyo. Hasil penelitian ini diperoleh bahwa \\
\hline & $\begin{array}{l}\text { pelaksanaan program perbaikan gizi kurang sudah berjalan, tetapi belum } \\
\text { secara maksimal. Hal ini dipengaruhi kurangnya SDM dalam program } \\
\text { perbaikan gizi kurang, menurunnya pemberian PMT, dan pelaksanaan } \\
\text { pematauan gizi yang tidak merata. Kesimpulan dari penelitain ini diperoleh } \\
\text { masih kurangnya SDM dalam program perbaikan gizi kurang yang mana } \\
\text { menyebabkan pemamtauan status gizi dan pemberian PMT tidak merata. } \\
\text { Saran dari peneliti ialah bahwa perlunya penambahan SDM dalam } \\
\text { program perbaikan gizi kurang, meningkatkan pemberian PMT, dan } \\
\text { pemantauan status gizi pada balita. }\end{array}$ \\
\hline & : Program, Sdm, Pmt, Pelaksanaan, Status gizi \\
\hline & ABSTRACT \\
\hline & $\begin{array}{l}\text { Malnutrition is one of the main nutritional problems in Indonesia so that the } \\
\text { Government emphasizes nutrition improvement programs with the aim of } \\
\text { increasing the health status and nutritional status of the community. } \\
\text { Puskesmas Sidomulyo is an area with the highest incidence of malnutrition } \\
\text { in children under five in Pekanbaru city with a total of } 69 \text { patients. This } \\
\text { research is qualitative analytic which aims to get an overview of the } \\
\text { malnutrition improvement program using in-depth interviews and } \\
\text { observations on malnutrition improvement programs at Puskesmas }\end{array}$ \\
\hline
\end{tabular}


Sidomulyo. The result of this research is that the implementation of the malnutrition improvement program has been running, but not maximall. This is influenced by the SDM in the program to improve malnutrition, decreased provision of PMT, and implementation of uneven nutrition monitoring. The conclusion of this research is that there is still a SDM in the undernutrition improvement program which causes the monitoring of nutritional status and the provision of PMT to be uneven. Suggestions from researchers are the need for additional SDM in the program to improve malnutrition, increase PMT provision, and monitoring the nutritional status of children under five.

Keywords: Program, Sdm, Pmt, Implementation, Nutritional status

\section{PENDAHULUAN}

Gizi kurang adalah gangguan kesehatan akibat kekurangan atau ketidakseimbangan zat yang diperlukan untuk pertumbuhan, aktifitas berfikir dan semua hal yang berhubungan dengan kehidupan gizi. Gizi kurang banyak terjadi pada balita usia kurang dari 5 tahun, kurang gizi yang mencakup kekurangan protein (WHO, 2005).

Gizi kurang menjadi salah satu masalah gizi utama di Indonesia sehingga Pemerintah menekankan program Indonesia sehat dengan sasaran meningkatkan derajat kesehatan dan status gizi masyarakat melalui upaya kesehatan dan pemberdayaan masyarakat yang di dukung dengan perlindungan finansial dan pemerataan pelayanan kesehatan dalam pembangunan kesehatan periode 2015 - 2019 (Badan Perencanaan Pembangunan Nasional, 2012).

Masa balita adalah masa kehidupan yang sangat penting dan perlu perhatian yang serius karena pada masa ini berlangsung proses tumbuh kembang yang sangat pesat. Pola asuh adalah salah stau faktor yang berkaitan dengan tumbuh kembang balita. Peran orang tua dalam proses pengasuhan sangat penting, pemberian nutrisi yang lengkap dan seimbang dapat menjadi dasar untuk tumbuh kembang balita yang optimal (Fikawati dkk, 2015).

Masalah gizi kurang ini menjadi masalah kesehatan masyarakat dan dapat menjadi penyebab kematian terutama pada kelompok risiko tinggi (bayi dan balita). Gizi kurang pada balita tidak terjadi secara tiba-tiba, tetapi diawali dengan keterbatasan kenaikan berat badan yang tidak cukup. Perubahan berat badan balita dari waktu ke waktu merupakan petunjuk awal perubahan status gizi balita. Dalam periode 6 bulan bayi yang berat badan tidak naik dua kali berisiko mengalami gizi kurang 12,6 kali dibandingkan pada balita yang berat badannya naik terus (Depkes $\mathrm{Rl}, 2017$ ). 
Dampak akibat gizi kurang pada balita ialah dapat menghambat pertumbuhan dan perkembangan balita itu sendiri, anak yang menderita gizi kurang tidak dapat tumbuh secara optimal, kekurangan tenaga untu bergerak, bekerja dan melakukan aktifitas, kecerdasan otak dan pertumbuhan pada tubuh balita sehingga mengakibatkan lambatnya berpikir, penurunan berat badan serta terjadinya balita pendek (Diniyyah \& Nindya, 2017).

Berdasarkan data yang di peroleh dari United Nations Childrens Fund (UNICEF) angka kejadian gizi kurang atau gizi buruk pada balita yang mengalami gizi dimana berat badannya di bawah standar sesuai usinya. Gizi kurang tersebut berada di atas batas WHO sebesar $20 \%$. Negara indonesia menempati posisi ke dua dengan besar 36,4\% dan di posisi pertama negara laos sebesar 43,8\%. Namun, berdasarkan pemantauan status gizi (PSG) 2017, balita yang mengalami masalah gizi kurang tercatat sebesar $26,6 \%$, angka tersebut terdiri dari $9,8 \%$ masuk katagori balita sangat kurus dan kategori kurus sebesar 19,8\%.

Menurut Peraturan Menteri Kesehatan Republik Indonesia Nomor 14 Tahun 2019 tentang pelaksanaan teknis surveilans gizi, bahwa dalam rangka mengoptimalkan pelaksanaan surveilans gizi dalam pengambilan keputusan , penyusunan kebijakan perbaikan gizi, dan melaksanakan upaya perbaikan gizi. (Permenkes RI, 2019).

Berdasarkan data yang di peroleh dari riset kesehatan dasar (Riskesdas) tahun 2018, angka kejadian gizi kurang di indonesia sebesar 13,8\%. Masalah gizi kurang ini tersebar ke 34 provinsi, yang mana angka kejadian gizi kurang terbesar terdapat pada provinsi Nusa Tenggara Timur sebesar 22,2\%, dan Nusa Tenggara barat 20,5\%. Sedangkan di provinsi riau angka kejadian gizi kurang sebesar $14,0 \%$ pada balita. (Kemenkes $R I, 2018$ ).

Berdasarkan data yang di dapat di Dinas Kesehatan Kota Pekanbaru bahwa diantara beberapa Puskesmas yang ada di kota Pekanbaru, terdapat tiga Puskesmas dengan jumlah balita yang menderita gizi kurang tertinggi yaitu Puskesmas Senapelan $(0,88 \%)$, Puskesmas Garuda $(1,04 \%)$ dan Puskesmas Sidomulyo (1,28\%) berdasarkan balita yang ditimbang. Puskesmas Sidomulyo merupakan Puskesmas dengan data balita gizi kurang tertinggi. yaitu sebanyak 69 balita yang terkena gizi kurang di tahun 2018 berdasarkan jumlah balita yang ditimbang di tahun 2018 yaitu sebanyak 5381 Balita yang di timbang, sedangkan jumlah keseluruhan balita yang ada di Puskesmas Sidomulyo ialah sebanyak 7295 balita yang ada di Puskesmas Sidomulyo (Dinkes Kota Pekanbaru,2018).

Dari hasil data yang di dapat pada Puskesmas Sidomulyo Kecamatan Tampan Kota Pekanbaru terhadap target dan pencapaian program gizi kurang pada balita tahun 2017 yang telah di capai $1,07 \%$ dari $8,6 \%$, pada tahun 2018 yang telah di capai $0,95 \%$ dari $8,5 \%$, dan pada tahun 2019 yang telah di capai 1,2\% dari 8,5\%, sehingga capaian target untuk masalah 
gizi kurang untuk di puskesmas sidomulyo masih jauh dari target yang telah ditetapkan (Puskesmas Sidomulyo, 2019).

Berdasarkan survei awal yang dilakukan pada masalah gizi kurang di Puskesmas Sidomulyo kecamatan tampan kota pekanbaru, didapat data awal tenaga kesehatan pemegang program gizi berjumlah dua orang, sedangkan jumlah balita yang ada di wilayah kerja Puskesmas Sidomulyo Kecamatan Tampan berjumlah 5785 balita. Berdasarkan wawancara awal yang dilakukan pada dua orang pemegang program gizi yang selalu aktif turun kelapangan hanya satu orang, masih kurangnya tenaga kesehatan lainnya yang membantu dalam pemantauan status gizi pada balita di wilayah puskesmas sidomulyo. Pihak petugas pemegang program gizi mengatakan masih kurangnya sarana dan prasarana seperti brosur, spanduk, liflet, dan media lainnya, masih adanya kekurangan pembiayaan dalam program gizi dalam turun kelapangan sehingga petugas pemegang program gizi memakai uang saku sendiri.

Menurut petugas program gizi masyarakat mengalami kesulitan untuk mendapatkan pelayanan kesehatan dengan alasan tidak memiliki transportasi dan sibuk bekerja, berpindahnya sasaran timpat tinggal balita gizi kurang sehingga dapat menyulitkan

atau memberhentikan pemantauan yang telah dilakukan pihak Puskesmas Sidomulyo. Berasarkan wawancara awal yang telah dilakukan pada dua orang tua yang membawa balita nya ke puskesmas sidomulyo diketahui bahwa rata-rata ibu balita tersebut tidak mengetahui terlalu banyak tentang gizi kurang, tidak terlalu paham dalam pemberian makanan yang bergizi untuk balita, tidak terlalu mengerti bagaimana cara pemberian pola asuh yang baik untuk balitanya.

\section{METODE}

Jenis penelitian ini adalah penelitian yang bersifat kualitatif analitik yang bertujuan untuk mendapatkan gambaran umum mengenai pelaksanaan program perbaikan gizi kurang di Puskesmas Sidomulyo kota pekanbaru, penelitian menggunakan pendekatan atau metode penelitian kualitatif, dengan metode wawancara mendalam dan observasi. Penelitian ini dilakukan di Puskesmas Sidomulyo kecamatan tampan kota pekanbaru yang dilaksananakan pada bulan febuari sampai bulan Juli tahun 2020. 


\section{HASIL}

\section{Evaluasi}

Menurut informasi yang didapat pada informan utama mengetahui ada nya tenaga gizi dalam program perbaikan gizi kurangberjumlah 2 orang. Beda hal nya informan kunci mengetahui tenaga gizi dalam program perbaikan gizi kurang berjumlah 3 orang. Sebagai mana wawancara berikut :

.."kalo tenaga kesehatan sendiri di puskesmas sidomulyo ada dua kita saya mita, dan yufi satu lagi jadi kami di gizi itu berdua tapi kalo di ruangan itu sendiri dibantu sama promkes sama adm emulator

.."(informan PJ)

...”... cukup ..cukup tenaga kesehatan untuk ee. Pemegang program giji nya sendiri ada tiga orang sekarang.."(informan KP)

..."...udah... anggotanya kan,,, udah..."(informan KD)

Menurut informasi yang di dapatkan dari informan utama mengetahui tenaga gizi yang berjumlah 2 orang masih kurang dalam pelaksanaan program perbaikan gizi kurang. Beda hal nya informan kunci mengetahui bahwa sudah cukup bisa melaksanakan program perbaikan gizi kurang . Sebagaimana kutipan berikut:

...”...eee kalo menurut saya sih masih kurang ya karna kan wilayah kita termasuk wilayah yang luas,, ada tiga kelurahan dimna padat penduduk gitu teruss kalo memang berdua dan di tambah lagi eee... ada yang dapat tugas tambahan ya kalo kayak di puskesmas kan kita ada tugas tambahan selain megang tenaga gizi nya gitu kan jadi terkadang tersangkut masalah itu, misalnya mau turun ada jadwal yang lain seperti itu.."(informan PJ)

.......bisa.. bisa.. iyah bisa karna kordinasi eee pemegang program lain nya lintas program kita ada koordinasi pekerjaan.."(informan KP).

\section{PEMBAHASAN}

\section{Sumber Daya Manusia}

Berdasarkan hasil penelitian yang telah di lakukan kepada informan utama didapatkan informasi bahwa tenaga gizi dalam program perbaikan gizi masih kurang dan informan kunci mengatakan sudah berjalannya program gizi tersebut. Hal ini di buktikan masih banyak nya jumlah balita gizi kurang di wilayah kerja Sidomulyo yang mana menyebabkan pelaksanaan program perbaikan gizi tidak berjalan secara maksimal. 
Berdasarkan observasi yang telah dilakukan didapatkan informasi bahwa sumber daya manusia yang terlibat dalam program perbaikan gizi kurang pada balita yaitu penanggung jawab program perbaikan gizi yang berjumlah 2 (dua) orang, kader posyandu, dan lainnya. Teori ini sesuai dengan teori Aeda Ernawati (2019) menyatakan Sumber daya manusia (SDM) yang sangat dibutuhkan terkait penanganan gizi buruk atau gizi kurang adalah petugas gizi Puskesmas yang terlatih dan kader Posyandu yang terampil. Penelitian ini sejalan dengan penelitian Wihelmus Kopong Doren. Dkk (2019) menunjukan bahwa secara kuantitas jumlah tenaga kesehatan bagian gizi masih kurang untuk melaksanakan tugas PMT karena berdasarkan hasil wawancara jumlah dan pendidikan yang ideal untuk tenaga kesehatan di Poli Gizi.

Menurut peneliti, hasil penelitian ini didapatkan bahwa SDM dalam program perbaikan gizi kurang di wilayah Puskesmas masih kurang, sehingga berjalannya program perbaikan gizi tersebut belum secara maksimal dalam pemberian PMT dan pemantauan status gizi kurang. Agar program gizi terlaksanan dengan baik perlunya ditambah tenaga gizi dalam program perbaikan gizi sehingga dapat berjalan secara maksimal.

\section{Pelaksanaan Program Perbaikan Gizi Kurang}

Berdasarkan hasil penelitian didapatkan informasi yang di dapat dari informan bahwa pelaksanaan program perbaikan gizi sudah berjalan, tetapi belum secara maksimal. Hal ini di buktikan oleh kurang nya tenaga gizi dalam program perbaikan gizi kurang di Puskesmas Sidomulyo yang menyebabkan pemberian PMT dan pemantauan status gizi pada balita mulai menurun atau tidak merata.

Berdasarkan observasi yang telah dilakukan di dapatkan informasi bahwa pelaksanaan program gizi kurang belum berjalan dengan maksimal, hal ini di buktikan dengan pemberian PMT dan pemantauan status gizi di lapangan atau di lokasi rumah balita gizi kurang tidak berjalan secara rutin.

Teori ini sesuai dengan teori Wihelmus Kopong Doren. Dkk (2019) mengatakan bahwa setiap program yang telah ditetapkan akan dijalankan oleh setiap pengelola dan juga pelaksanan program, dalam menjalankan setiap perorangpun perlu adanya kerjasama lintas sektor hal ini dilakukan karena setiap program tidak bisa berdiri sendiri dalam melaksanakan tugas mereka. Penelitian ini sejalan dengan penelitian Elya Sugianti (2017) mengatakan pelaksanaan dalam program gizi belum berjalan dengan baik karena masih adanya ketidaksamaan pendapat antara dinas kesehatan dan petugas pelaksana gizi puskesmas. 
Menurut peneliti, hasil penelitian ini di dapatkan bahwa pelaksanaan program perbaikan gizi kurang di Puskesmas Sidomulyo sudah berjalan, tetapi belum secara maksimal. hal ini disebabkan kurangnya tenaga gizi dalam program perbaikan gizi sehingga pelaksanaan pemberian PMT atau pemantauan status gizi dalam program perbaikan gizi tidak terlaksana secara rutin atau menurun. agar pelaksanaan program perbaikan gizi kurang pada balita supaya berjalan secara maksimal adanya penambahan tenaga gizi dalam program perbaikan gizi kurang pada balita sehingga pemberian PMT dan pelaksanaan pemantauan status gizi pada balita gizi kurang dapat di lakukan secara rutin.

\section{SIMPULAN}

Berdasarkan hasil penelitain dan pembahasan dapat di simpulakan program perbaikan gizi kurang pada balita di wilayah kerja Puskesmas Sidomulyo belum berjalan dengan baik. Hal ini dapat depengaruhi oleh beberapa faktor: Secara kuantitas SDM yang terlibat dalam program perbaikan gizi kurang pada balita masih kurang. Hal ini di karenakan banyaknya penduduk atau masyarakat yang berada di wilayah kerja Puskesmas Sidomulyo.

\section{SARAN}

Terkait jumlah tenaga gizi dalam program perbaikan gizi kurang pada balita perlunya ditambah dan ditingkatkan, sehingga pelaksanaan program perbaikan gizi kurang dan pemberian PMT pada balita di wilayah kerja puskesmas dapat berjalan secara maksimal Dan penggunaan sarana dan prasarana perlu dipermudah agar bisa di bawa turun ke lapangan.

\section{UCAPAN TERIMAKASIH}

Ucapan terima kasih ditujukan kepada Puskesmas Sidomulyo Kota Pekanbaru yang telah memberikan izin penelitian.

\section{DAFTAR PUSTAKA}

Arum,S.P.,\& Mahmudiono,T.(2020). Efektivitas Pemberian Makanan Tambahan (PMT) Pemulihan Pada Status Gizi Balita di Wilayah Kerja Puskesmas Simomulyo, Surabaya Effectiveness of Supplementary Feeding Recovery on Children Under Five Nutritional Status in Simomulyo Health Center Work Area, Surabaya. 10, 58-64. 
Affrian, R. (2018). Implementasi Program Perbikan Gizi Masyarakat Kategori. 3(1), 1521.

Akademi, A., \& Pekanbaru, H. (2017). Pola pemberian makan pada balita gizi buruk di kelurahan rumbai bukit kota pekanbaru. 2(February).

Bakri, B., \& Rahman, N. (2019). Kualifikasi Tenaga Kerja Pada Berbagai Klasifikasi Penyelenggaraan Makanan Massal (Tinjauan Berdasarkan Jumlah Konsumen dan Jenis Menu Yang Disajikan ). 17, 35-49.

Balita, P., Gizi, K., \& Kabupaten, D. I. (2017). Evaluation Of Feeding'S Programme To The Malnutrition. 11(2), 217-224.

Bulan, U., Wilayah, D. I., Puskesmas, K., \& Kota, L. (2018). No Title. 3(2), 8-15.

Centers, H., \& Barat, P. (2016). Analisis Implementasi Program Penanggulangan Gizi Buruk Di Puskesmas Wilayah Kerja Dinas Kesehatan Kota Sorong Provinsi Papua Barat Analysis on the Implementation of Malnutrition Alleviation Program at Primary. 04(01).

Dinas Kesehatan Kota Pekanbaru.(2018). Laporan kinerja dinas kesehatan kota pekanbaru tahun 2018.

Depkes RI. (2018). Enam Provinsi Sulit Keluar Dan Permasalahan Kemiskinan dan Prevalensi Gizi Kurang.

Doren, W. K., Regaletha, T. A. L., \& Dodo, D. O. (2019). Evaluasi Program Pemberian Makanan Tambahan Pemulihan ( PMT-P) Terhadap Status Gizi Buruk Balita di Puskesmas Oepoi Kota Kupang Fakultas Kesehatan Masyarakat - Universitas Nusa Cendana Lontar: Journal of Community Health Fakultas Kesehatan Masyarakat Universitas Nusa Cendana. 01(September), 111-118.

Ernawati, A., Perencanaan, B., Daerah, P., \& Pati, K. (2019). Analisis implementasi program penanggulangan gizi buruk pada anak balita di puskesmas jakenan kabupaten pati analysis of the implementation of children undernutrition improvement program in jakenan health centre pati regency. XV(1), 39-50.

Fikawati dkk. (2015). Determinan Gizi Kurang Dan Stunting Anak Umur 0-36 Bulan Berdasarkan Data Program Keluarga Harapan. Jurnal Gizi dan Pangan. Vol 7, No.1, Maret 2015

Gizi, J., Kesehatan, P., \& Aceh, K. (2017). Terhadap Status Gizi Balita ( Effect of supplementary feeding modification on nutritional status of toddler ). 2(November), 120 125.

Gizi, D., IImu, F., \& Surakarta, U. 
M. (2018). Original Article Tambahan Balita Dengan Perubahan Status Gizi Balita Di Puskesmas Pucangsawit Surakarta Change Nutritional

Status In Pucangsawit Health Center Surakarta. 1(2), 92-100.

Indonesia, M. K., \& Desa, B. (2015). Evaluasi Program Pemberian Makanan Tambahan Pemulihan pada Balita Kurang Gizi di Kabupaten Wonogiri Ditinjau dari Aspek Input dan Proses Supplementary Feeding Program Evaluation Restoration Malnourished In Children Under Five In The District Wonogiri Seen From Input and Process Aspects. 03(01).

Kementrian Kesehatan, RI. (2014). Upaya Perbaikan Gizi. Jakarta

Kalsum, U., \& Jahari, A. B. (n.d.). Strategi Menurunkan Prevalensi Gizi Kurang Pada Balita di Provinsi Jambi.

Kasus, S., Malam, S., Sumbertimo, D., \& Arjosari, D. (2015). Pendampingan Upaya Perbaikan Gizi pada Balita. 1.

Khasanah, N. A., \& Sulistyawati, W. (2018). Karakteristik Ibu dengan Kejadian Gizi Kurang pada Balita 6-24 Bulan di Kecamatan Selat, Kapuas Tahun 2016. 7(1), 1-8.

Kesehatan, J., \& Vol, R. (2016). Kementerian kesehatan republik indonesia. 7(April).

Kementrian Kesehatan, (2018). Laporan nasional riskesdas tahun 2018.

Masitoh, S., \& Laelasari, E. (2019). Gambaran Ketersediaan Sumber Daya Manusia dan Prasarana Puskesmas dalam Pelaksanaan Program Indonesia Sehat dengan Pendekatan Keluarga ( PIS-PK): Analisis Data Risnakes 2017 Availability of the Human Resources ( HR ) and Primary Health Care's Infrastructure in the Implementation of Program Indonesia Sehat dengan Pendekatan Keluarga ( PIS-PK ): Data Analysis of Risnakes 2017. 3(1), 31-39.

Nasution, S. I., \& Liputo, N. I. (2016). Artikel Penelitian Faktor-Faktor yang Berhubungan dengan Pola Pemberian ASI Eksklusif di Wilayah Kerja Puskesmas Bungus Tahun 2014. 5(3), 635-639.

Novela, V., \& Kartika, L. (2019). Faktor-Faktor Status Gizi Kurang Pada Anak Usia Prasekolah di Wilayah Kerja Puskesmas Guguk Panjang Kota Bukittinggi. 4(2).

Profil Puskesmas Sidomulyo Tahun 2018

Puskesmas, P. (2018). Gizi Buruk Dan Inter-Professional Collaboration. 11(1).

Permenkes Rl,(2019).pelaksanaan surveilens gizi 
Ridwan, E. (2010). Cakupan Suplementasi Kapsul Vitamin A Dalam Akses Pelayanan Kesehatan Pada Anak Balita Di Indonesia Analisis Data Riskesdas 2010 ( Vitamin A Supplementation Coverage in Relationship to Household Characteristics and Access to Health Care Among Children Under Five Years Old in Indonesia Data Analyzed of Baseline Health Research 2010). 2010, 1-9 